\title{
Takecallis arundinariae (Essig) (Aphididae, Drepanosiphinae, Phyllaphidini) - first record in Brazil and comparison to Takecallis taiwanus (Takahashi)
}

\author{
Sonia Maria Noemberg Lazzari ${ }^{2}$ \\ Regina Celia Zonta de Carvalho ${ }^{3}$ \\ Josiane Teresinha Cardoso ${ }^{2}$
}

\begin{abstract}
This paper reports the first record of a bamboo aphid Takecallis arundinariae (Essig, 1917) on bamboo plants in Curitiba, Paraná, Brazil. Specimens were also collected in yellow pan traps from June-August (fall-winter), and a few specimens from October-December (late spring-early summer). Individuals were found feeding on the underside of leaves, parallel to the veins on Dendroclamus sp. and Merostachys sp. (Bambusoideae). Individuals collected were represented mainly by alate viviparous females bearing a characteristic clypeus with an anterior tubercle. A brief diagnosis and morphometric data are presented to distinguish $T$. arundinariae from Takecallis taiwanus (Takahashi, 1926), another bamboo aphid recorded recently in Brazil. $T$. arundinariae is a medium-sized pale yellow aphid, distinguished by a series of elongate black spots on the abdominal tergites and found mainly on mature bamboo leaves. T. taiwanus is pale green and has been found on young leaves and shoots.

KEY WORDS. Aphididae, Takecallis, bamboo aphids, occurrence, Bambusoideae
\end{abstract}

The genus Takecallis Matsumura, 1917 (Aphididae, Drepanosiphinae, Phyllaphidini) includes six species (REMAUDIÈRE \& REMAUDIÈRE 1997) and resembles Myzocallis Passerini, 1860, but may be distinguished from the later by the clypeus bearing an anterior tubercle (Figs la,e,f), the processus terminalis approximately equal in length to the base of antennal segment VI, the short rostrum, reaching a little beyond the fore coxae, and by the $8^{\text {th }}$ abdominal segment with $2-4$ setae (HIGUCHI 1968). This genus is Oriental or eastern Palaearctic in origin (HIGUCHI 1968), but some species have been introduced into parts of Europe, New Zealand, North America, and South Africa. All Takecallis species live on bamboos (Poaceae: Bambusoideae), such as Arundinaria, Bambusa, Phyllostachys, Pleioblastus, and Sasa (BLACKMAN \& EASTOP 1984, 1994).

Takecallis arundinariae (Essig, 1917) is native in India, China, Taiwan, Japan, and was introduced to England, New Zealand, and North America. The life

1) Contribuição número 1166 do Departamento de Zoologia, Universidade Federal do Paraná.

2) Departamento de Zoologia, Universidade Federal do Paraná. Caixa Postal 19020, 81531-990 Curitiba, Paraná, Brasil. CNPq fellows.

E-mail: lazzari@bio.ufpr.br

3) Centro de Diagnóstico Marcos Enrietti, SEAB. Rua Jaime Balão 575, 80040-340 Curitiba, Paraná, Brasil. 

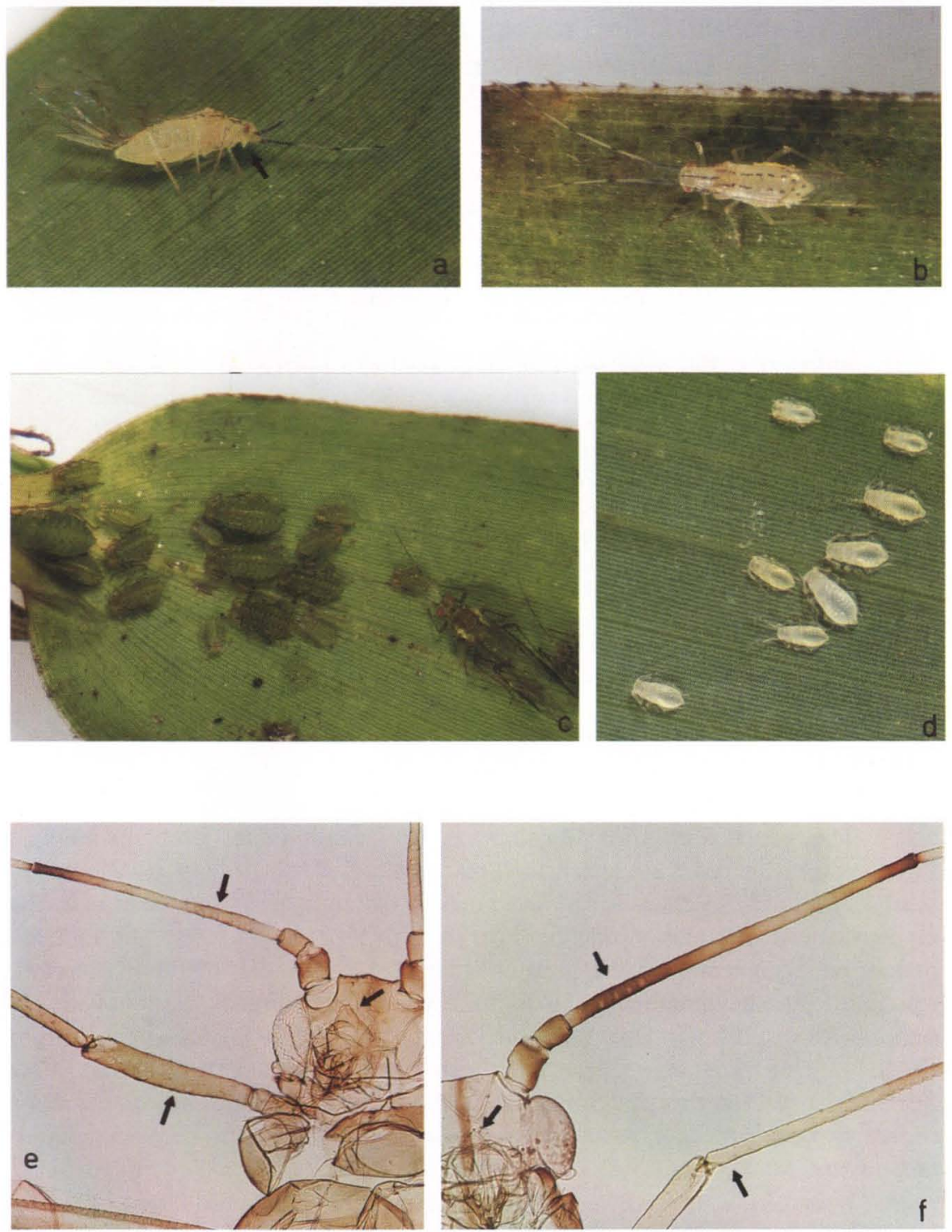

Fig. 1. Takecallis arundinariae, alate viviparous females: (a) clypeus with tubercle; (b) spots on dorsum; ( $f$ ) mounted specimen showing clypeal tubercle, dark sensorial portion of antennal segment III, and pale leg; (d) young nymphs on bamboo leaf. Takecallis taiwanus, alate viviparous females: (c) colony with adult and nymphs on bamboo leaf; (e) mounted specimen showing clypeal tubercle, pale sensorial portion of antennal segment III, and dark leg.

Revta bras. Zool. 16 (3): 865 - 870, 1999 
cycle is unknown in its native range; it is probably anholocyclic where introduced. Usually, all viviparae are alates; sexual morphs have not been reported and an apterous morph has been described, but only from high altitudes in Taiwan (BLACKMAN \& EASTOP 1984, 1994).

COFFELT \& SCHULTZ (1990) investigated the seasonal abundance and population dynamics of $T$. arundinariae on golden stem bamboo Phyllostachys aurea (Carrie're), in Virginia. They observed that $T$. arundinariae population dynamics were strongly influenced by climatic conditions and peaks of abundance corresponded closely to the cool temperatures in spring and late fall-early winter. CHAKRABARTI (1981) apud COFFELT \& SCHULTZ (1990), reviewed the distribution and seasonal abundance in India and found $T$. arundinariae populations when temperatures were low and day-length short.

COFFELT \& SCHULTZ (1990) observed that when T. arundinariae populations were at constant or rising levels, significantly more nymphs were found in the southern and eastern quadrants than in the northern and western quadrants of the bamboo grove. This directionality may have allowed the population to be exposed to increasing sunlight and weaker winds during the winter and early spring periods. Adults and larvae of Chrysopidae and Coccinellidae and larvae of Syrphidae were found, but parasites or mummies were not.

Another bamboo aphid, Takecallis taiwanus (Takahashi, 1926) has been recently recorded on Phyllostachys cf. aurea, in Minas Gerais, Brazil (FoUREAUX \& KATO 1999).

\section{MATERIAL AND METHODS}

The survey was carried out from December 1997 to December 1998 in the Centro Politécnico campus of the Universidade Federal do Paraná, Curitiba, Paraná, southern Brazil, at $25^{\circ} 25^{\prime} 04^{\prime \prime} \mathrm{S}$ and $49^{\circ} 14^{\prime} 30^{\prime \prime} \mathrm{W}$, altitude $945 \mathrm{~m}$ a.s.l. Average annural temperature in the survey region is $16.5^{\circ} \mathrm{C}$ and average precipitation $1,451.8$ $\mathrm{mm} /$ year (MAACK 1981). Four Moericke's yellow pan traps were placed at different locations in the study area (about $650,000 \mathrm{~m}^{2}$ ) and were evaluated every two weeks. Bamboo plants from two groves in the campus grounds were examined sporadically since 1997 and in 1999. Slide-mounted specimens on balsam were measured under compound microscope and deposited in the "Coleção de Entomologia Pe. J.S. Moure" entomological collection, Departamento de Zoologia, Universidade Federal do Paraná (DZUP).

\section{RESULTS AND DISCUSSION}

Two species of Takecallis were collected on bamboo plants in Curitiba: $T$. arundinariae and T. taiwanus. Isolated alates and small groups of nymphs of $T$. arundinariae were found on Dendroclamus sp., feeding on the undersides of mature leaves, and a very few alates were found on Merostachys sp. (Poaceae: Bambusoideae) (Fig. 1d). These were the first records of $T$. arundinariae in Brazil. Larger colonies of $T$. taiwanus were found on shoots and young leaves of Dendroclamus sp. (Fig. 1c). This aphid species had already been collected in Contagem, Minas Gerais, Brazil on Phyllostachys cf. aurea (FOUREAUX \& KATO 1999). 
Alate viviparous females and nymphs of both species occurred on the plants from June through August, during fall-winter, and a few specimens were found from October to December, in late spring-early summer. A very low number of alates was captured in the traps during the collection period (Fig. 2). Numbers of individuals of $T$. arundinariae peaked at the end of July, corresponding to mid-winter, when average temperature was about $15^{\circ} \mathrm{C}$; another small peak in abundance was observed in early December, when temperature was about $20^{\circ} \mathrm{C}$. For T. taiwanus, only five specimens were collected in the yellow pan traps in mid-June and from the end of October to the end of December.
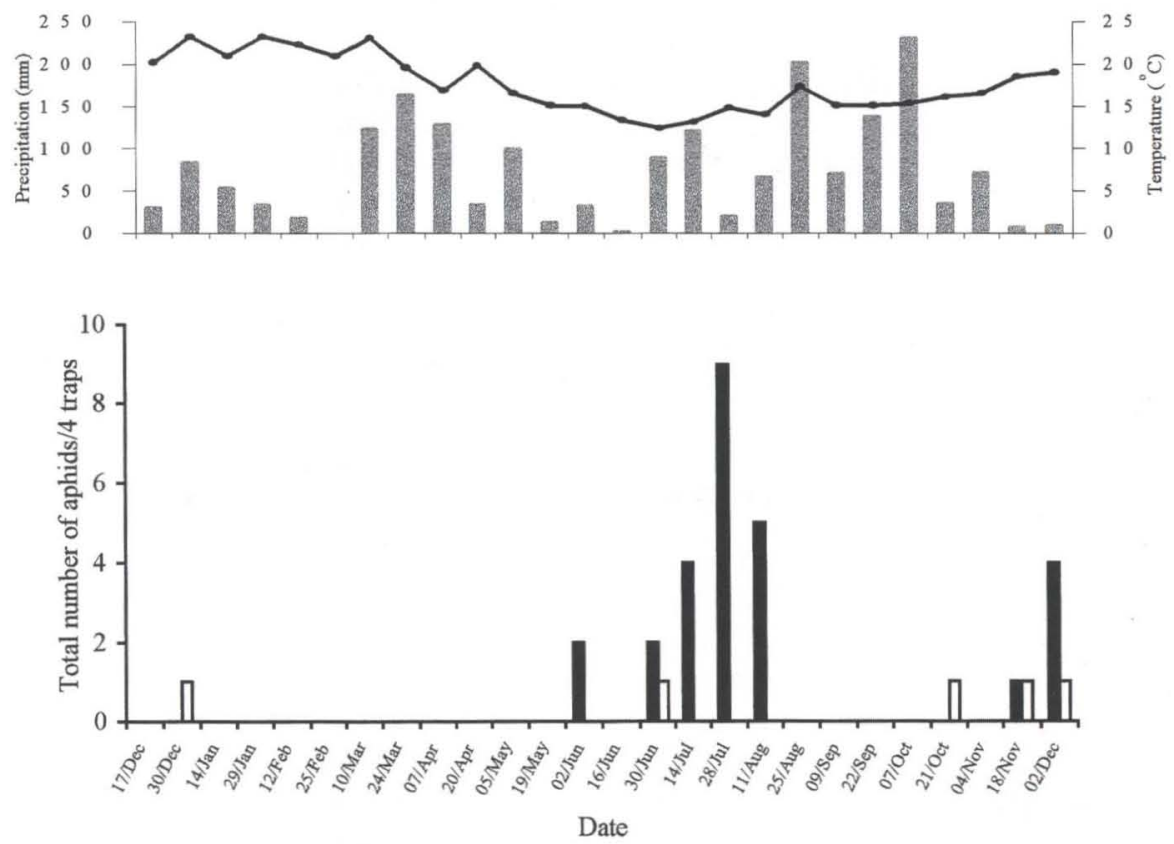

Fig. 2. Number of Takecallis arundinariae ( $\square$ ) and Takecallis taiwanus ( $\square$ ) captured with yellow pan traps, related to average temperature and precipitation, Curitiba, Paraná, Brazil, December/1997 - December/1998.

The results agree partially with those indicated by COFFELT \& SCHULTZ (1990) and CHAKRABARTI (1981) apud COFFELT \& SCHULTZ (1990), who mention the peak of abundance of the species occurring under cool temperatures during winter and early spring, with smaller populations during warm periods of the year. COFFELT \& SCHULTZ (1990) recorded the population peak of T. arundinariae in Virginia, USA, from March to May, corresponding closely to the cool temperatures in the spring; mean temperatures in April and May were $12.3^{\circ} \mathrm{C}$ and $18.3^{\circ} \mathrm{C}$, respectively, and such conditions induced rapid aphid population increase. A smaller peak was observed in December, corresponding to late fall-early winter, when the mean temperature was $5.6^{\circ} \mathrm{C}$. Aphid populations declined from June to 
October, when the mean monthly temperatures were the highest of the year $\left(25-28^{\circ} \mathrm{C}\right)$. CHAKRABARTI (1981) apud COFFELT \& SCHULTZ (1990), observed that $T$. arundinariae populations in India had their peak of abundance during low December (winter) temperatures with short- day-length; aphids were not found during warm, summer temperatures, from April to June.

Table I indicates that all morphometric characters measured were longer in T. arundinariae than in T. taiwanus; it is noticeable that antennal segment III is much longer in the former species. The oblong body of $T$. arundinariae is 1.42-2.45 $\mathrm{mm}$ in length including cauda; antennae are 1.34-1.52 times longer than body and the processus terminalis is about 1.12-1.50 times longer than base of the segment VI. T. taiwanus is frequently smaller than $T$. arundinariae, not surpassing $1.83 \mathrm{~mm}$. Antennae are 0.83-0.98 times the body length and processus terminalis is about $0.95-1.10$ times the base of the segment.

Table I. Morphological characters for alate viviparous females of Takecallis arundinariae and Takecallis taiwanus collected from Dendroclamus sp., in Curitiba, Paraná, Brazil, June/1999.

\begin{tabular}{lcc}
\hline \multirow{2}{*}{ Character } & \multicolumn{2}{c}{ Length $(\mathrm{mm})$} \\
\cline { 2 - 3 } & T. arundinariae $(\mathrm{n}=18)$ & T. taiwanus $(\mathrm{n}=10)$ \\
\hline Body & $1.42-2.45$ & $1.57-1.83$ \\
Antennae & $2.06-3.34$ & $1.39-1.61$ \\
Antennal segment III & $0.56-1.05$ & $0.46-0.54$ \\
Antennal segment IV & $0.41-0.74$ & $0.25-0.32$ \\
Antennal segment V & $0.39-0.66$ & $0.23-0.30$ \\
Base of antennal segment VI & $0.21-0.35$ & $0.15-0.18$ \\
Processus terminalis & $0.32-0.42$ & $0.15-0.18$ \\
\hline
\end{tabular}

\section{Diagnosis}

\section{Takecallis arundinariae}

The alate viviparous female is a medium-sized pale yellow aphid in life, with elongate dark patches on abdominal tergites; antennae longer than body; wing veins slightly smoked (Figs 1a,b); feeding preferentially on underside of mature bamboo leaves, parallel to the veins, and dispersing easily when touched. The nymphs are very pale and apparently smooth (Fig. 1d).

Cleared specimens (Fig. 1f) have pale head and thorax with longitudinal dark stripes; abdomen bearing pair of elongate dark patches on tergites 1-7; antennal segments I, II, sensorial part of III, and articulations of III, IV and V are as dark as patches on abdominal tergites; coxae, trochanters and femora pale, apices of tibiae and tarsi are usually light-brown; siphunculi pale; cauda knobbed and fumeus.

\section{Takecallis taiwanus}

Alate viviparous female is pale green in life, without markings on abdominal tergites, but with $1^{\text {st }}$ and $2^{\text {nd }}$ abdominal segments bearing conspicuous spinal tubercles; antennae as long as or shorter than body; slightly smoked veins on the wings; feeding on young leaves and shoots (Fig. 1c). Nymphs are bright green with rows of spines on dorsum (Fig. 1c). 
Cleared specimens (Fig. 1e) have a longitudinal smoked stripe on mid-head; thorax is light brown without stripes; abdominal tergites without dark markings; sensorial portion of antennal segment III is pale; I, II, apex of III and IV antennal segments are dark brown; legs are uniformly light brown; siphunculi pale with smoked apex; and fumeus knobbed cauda.

Since the first collection of these species on bamboos in Curitiba (at the end of 1997), we have observed that their populations are increasing, probably because they are adapting to the climate and hosts, and perhaps due to the low number of natural enemies. A few larvae and adults of Cycloneda sanguinea (Linnaeus, 1763) (Coleoptera, Coccinellidae) were found on the plants where the aphids were found. As observed for most aphid species, large populations of Takecallis may cause yellowing, leaf dropping, sooty mold development, and other injuries to the plants, especially to the ornamental species of bamboo. Continuous monitoring and studies of the population dynamics are warranted.

ACKNOWLEDGEMENTS. We are thankful to Dr. Victor F. Eastop, The Natural History Museum, London (BMNH), for confirming the aphid identification and to Dr. Gerdt Hatschbach, Museu Botânico Municipal de Curitiba, for the identification of the bamboos.

\section{REFERENCES}

Blackman, R.L \& V.F. EAStoP. 1984. Aphids on the World's Crops - An Identification and Information Guide. Chichester, John Wiley and Sons, 466p.

. 1994. Aphids on the World's Trees - An Identification and Information Guide. Wallingford, CAB International, 987p.

CoffelT, M.A. \& P.B. SchulTZ. 1990. Seasonal abundance and population dynamics of a bamboo aphid, Takecallis arundinariae (Homoptera: Aphididae). Jour. ent. Sci. 25 (4): 526-534.

FoureauX, L.V. \& C.M. KaTo. 1999. Primeiro registro de Takecallis taiwanus (Takahashi) (Homoptera: Aphididae) no Brasil. An. Soc. Entomol. Brasil 28 (1): 183-184.

HiguCHI, H. 1968. A revision of the genus Takecallis Matsumura (Homoptera: Aphididae). Insecta matsum. 31 (4): 25-34.

MAACK, R. 1981. Geografia Física do Estado do Paraná. Rio de Janeiro, Editora José Olympio, 450p.

REMAUdiÉRE, G. \& M. REMAUdiÈRE. 1997. Catalogue of the World's Aphididae. Paris, INRA, 473p. 